\title{
Effects of Trans-10, Cis-12 Conjugated Linoleic Acid on Ovine Milk Fat Synthesis and Cheese Properties ${ }^{1}$
}

\author{
L. A. Sinclair, ${ }^{* 2}$ A. L. Lock, $†$ R. Early, ${ }^{*}$ and D. E. Bauman $\ddagger$ \\ ${ }^{*}$ Animal Science Research Centre, Harper Adams University College, Edgmond, Newport, Shropshire, TF10 8NB, United Kingdom \\ †Department of Animal Science, University of Vermont, Burlington 05405 \\ ‡Department of Animal Science, Cornell University, Ithaca, NY 14853
}

\section{ABSTRACT}

Trans-10, cis-12 conjugated linoleic acid (CLA) reduces milk fat synthesis in sheep in a manner similar to that seen in dairy cows, but its effects on cheese yield and flavor are unknown. Additionally, when dietary energy supply is restricted, CLA can increase milk and milk protein yield, which may alter cheese yield and eating quality. The objectives of the study were to examine the effects of supplementing ewe diets with a rumenprotected source of CLA at a high and low dietary energy intake on milk fat and protein synthesis and on cheese yield and eating quality. Sixteen multiparous ewes were randomly allocated to 1 of 4 dietary treatments: a high (6.7 Mcal of metabolizable energy/d) or low (5.0 Mcal of metabolizable energy/d) feeding level that was either unsupplemented or supplemented with $25 \mathrm{~g} / \mathrm{d}$ of a lipid-encapsulated CLA (to provide $2.4 \mathrm{~g} / \mathrm{d}$ of CLA) in each of 4 periods of 21 d duration in a $4 \times$ 4 Latin square design. There was no effect of treatment on milk yield $(\mathrm{g} / \mathrm{d})$, but milk fat percentage and milk fat yield were reduced by 23 and $20 \%$, respectively, in ewes supplemented with CLA. Milk fatty acid concentration $(\mathrm{g} / 100 \mathrm{~g})$ of chain length $<\mathrm{C}_{16}$ was decreased and $>\mathrm{C}_{16}$ was increased in milk and cheese following CLA supplementation, whereas decreasing the feeding level increased fatty acids $\geq \mathrm{C}_{16}$. Milk fat contents of CLA were 0.01 and $0.12 \mathrm{~g} / 100 \mathrm{~g}$ of fatty acids for the unsupplemented and CLA-supplemented treatments, respectively, whereas cis-9, trans-11 CLA was unaffected by CLA supplementation. There was no main effect of treatment on cheese yield, which was $0.11 \pm$

Received January 4, 2007.

Accepted February 26, 2007.

${ }^{1}$ Supported in part by Harper Adams University College and by Cornell University Agricultural Experiment Station and funds received from Cooperative State Research, Education and Extension Service, USDA, under agreement No. NYC-127437. Any opinions, findings, conclusions, or recommendations expressed in this publication are those of the authors and do not necessarily reflect the views of the USDA.

${ }^{2}$ Corresponding author: lsinclair@harper-adams.ac.uk
$0.001 \mathrm{~kg}$ of cheese $/ \mathrm{kg}$ of milk, but cheese yield was highest, at $0.12 \pm 0.001 \mathrm{~kg} / \mathrm{kg}$, when made from milk of ewes fed the high feeding level + unsupplemented treatment. Cheese made from the milk of ewes supplemented with CLA, compared with the unsupplemented diet, was rated (scale 0 to 10) higher in the creaminess (2.1 vs. 1.4; SEM 0.15$)$ and less oily (0.8 vs. 1.3 ; SEM 0.17 ) attributes, and was preferred overall (4.5 vs. 3.9; SEM 0.21). Cheese produced from sheep on the high vs. low feed level was rated less yellow (2.8 vs. 4.2 ; SEM 0.11 ), less salty (1.9 vs. 2.3 ; SEM 0.15 ), and more sour (1.5 vs. 1.1; SEM 0.13). We concluded that the effect of feeding level on animal performance and cheese characteristics was small, whereas supplementing the diets of ewes with a ruminally protected CLA source reduced milk fat yield, did not affect cheese yield, and beneficially altered the flavor characteristics of the cheese.

Key words: cheese, conjugated linoleic acid, milk fat depression, sheep

\section{INTRODUCTION}

Milk from dairy ewes is characterized by a high fat content and a correspondingly low CN:fat ratio, at approximately 0.55 to 0.60 (Wendorff, 2002). For most full-fat type cheeses the preferred ratio is around 0.70; therefore, milk has to be standardized prior to processing to remove the surplus fat or the excess is lost in the whey. Because milk costs account for approximately $85 \%$ of the cost of sheep cheese production (Wendorff, 2002), this represents both a biological and an economic loss. Conjugated linoleic acids (CLA) are a mixture of positional and geometric isomers of 18:2 fatty acids that contain a conjugated double bond and are produced as intermediaries in the process of biohydrogenation of polyunsaturated fatty acids in the rumen (Bauman and Lock, 2006). Both short- and longer-term studies in dairy cows have established that the trans-10, cis-12 isomer is a potent inhibitor of milk fat synthesis, with milk fat synthesis being reduced in a dose-dependent manner. Investigations with other species are more limited, but recently it was reported that a lipid-encapsu- 
lated supplement containing trans-10, cis-12 CLA reduced milk fat synthesis in sheep to a similar extent as in dairy cows when sheep were fed at an equivalent rate on a metabolic basis (Lock et al., 2006). Increasing the mammary supply of trans-10, cis-12 CLA represents a suitable means to reduce milk fat content and improve the CN:fat ratio for cheese making. Supplementation with a ruminally protected CLA alters the fatty acid composition of milk, with an increase in the proportion of long-chain fatty acids and a reduction in de novoderived fatty acids (Bauman and Lock, 2006). These changes may affect the sensory attributes and eating quality of the subsequent cheese, but there have been no studies on the effects of CLA supplementation of dairy ewes on cheese quality.

Despite the consistent effects of trans-10, cis-12 CLA on reducing milk fat yield, studies with dairy cows have typically not observed an effect on milk or milk protein yield. Circumstances in which trans-10, cis-12 CLA was associated with an increase in milk yield, milk protein yield, or both include when the animal was undersupplied with dietary energy either in early lactation (Bernal-Santos et al., 2003) or when fed at a restricted level (de Veth et al., 2006), although no studies have directly examined the effect of feeding level and CLA supplementation on milk production. Additionally, decreasing the dietary energy supply may affect the $\mathrm{CN}$ :fat ratio in milk with subsequent effects on cheese yield and quality (Soryal et al., 2004). The objectives of this experiment were to examine the effects of supplementing dairy ewe diets with a rumen-protected source of trans10, cis-12 CLA, at a high and low dietary energy intake, on the synthesis of milk fat and protein and on the yield, composition, and eating quality of the cheese.

\section{MATERIALS AND METHODS}

The experiment was conducted in accordance with the UK Animals (Scientific Procedures) Act 1986.

\section{Animals and Experimental Procedure}

Sixteen multiparous lactating ewes (12 Friesland and 4 British Milksheep) were weaned from their lambs at approximately $3 \mathrm{wk}$ postpartum, penned individually, bedded on sawdust, and fed a complete diet containing concentrates and haylage (Lolium perenne; 0.65:0.35, $\mathrm{DM}$ basis). The diet was offered fresh daily at $0830 \mathrm{~h}$, and the ewes were milked twice daily at 0800 and 1600 $\mathrm{h}$ through a standard ewe milking parlor. Based on their milk and constituent yield, BW, and BCS (Russell et al., 1969) during wk 5 of lactation, the ewes were randomly allocated to 1 of 4 dietary treatments. The diets were based on barley, sugarbeet feed, soybean
Table 1. Ingredient composition and chemical analysis of concentrates and hay fed to lactating ewes

\begin{tabular}{|c|c|c|c|}
\hline Composition $^{1}$ & $\begin{array}{l}\text { High } \\
\text { feeding } \\
\text { level }\end{array}$ & $\begin{array}{l}\text { Low } \\
\text { feeding } \\
\text { level }\end{array}$ & Haylage \\
\hline \multicolumn{4}{|l|}{ Ingredient, $\mathrm{g} / \mathrm{kg}$} \\
\hline Barley (rolled) & 322 & 207 & \\
\hline Dried molassed sugarbeet feed ${ }^{2}$ & 367 & 240 & \\
\hline Corn gluten feed & 98 & 70 & \\
\hline Megalac & 46 & 46 & \\
\hline Rapeseed meal & 69 & 89 & \\
\hline Soybean meal & 13 & 156 & \\
\hline Sopralin $^{3}$ & - & 120 & \\
\hline Urea (feed grade) & 24 & 2 & \\
\hline Minerals and vitamins ${ }^{4}$ & 26 & 35 & \\
\hline Molasses & 35 & 35 & \\
\hline \multicolumn{4}{|l|}{ Chemical analysis } \\
\hline $\mathrm{DM}, \mathrm{g} / \mathrm{kg}$ & 852 & 862 & 661 \\
\hline Ash, g/kg of DM & 111 & 104 & $\mathrm{ND}^{5}$ \\
\hline $\mathrm{CP}, \mathrm{g} / \mathrm{kg}$ of $\mathrm{DM}$ & 228 & 274 & 106 \\
\hline $\mathrm{NDF}, \mathrm{g} / \mathrm{kg}$ of $\mathrm{DM}$ & 226 & 172 & 748 \\
\hline Starch, g/kg of DM & 194 & 170 & ND \\
\hline $\mathrm{ME}, \mathrm{Mcal} / \mathrm{kg}$ of $\mathrm{DM}$ & 3.2 & 3.2 & 1.7 \\
\hline \multicolumn{4}{|l|}{ Fatty acid content, g/kg of DM } \\
\hline $16: 0$ & 21.4 & 18.1 & 3.0 \\
\hline $16: 1$ cis -9 & 3.4 & 5.0 & 2.1 \\
\hline $18: 0$ & 2.1 & 1.6 & 0.5 \\
\hline $18: 1$ cis -9 & 17.1 & 13.2 & 1.6 \\
\hline $18: 2$ cis -9, cis -12 & 14.5 & 11.4 & 2.3 \\
\hline $18: 3$ cis -9, cis -12, cis -15 & 1.5 & 1.2 & 1.6 \\
\hline Total fatty acids & 70.3 & 60.9 & 20.4 \\
\hline
\end{tabular}

${ }^{1}$ Ingredient and chemical composition values do not include the lipid-encapsulated conjugated linoleic acid (CLA) supplement, which had a fat content of $65 \%$ (fatty acid composition was $9 \% 16: 0,42 \%$ 18:0, $12 \%$ cis-9 18:1, 1\% cis-9, cis-12 18:2, 15\% cis-9, trans-11 CLA, and 15\% trans-10, cis-12 CLA; Lock et al., 2006), or additional Megalac, a calcium soap of palm oil fatty acids (Volac Ltd., Royston, Hertfordshire, UK). Fatty acid composition, as reported by the company, was $1 \% 12: 0+14: 0,48 \% 16: 0,5 \% 18: 0,36 \%$ cis-9 18:1, and 9\% cis-9, cis12 18:2.

${ }^{2}$ By-product of the manufacture of sugar, consisting of extracted sugar beet slices and sugar beet molasses, which have been dried (Trident Feeds, Peterborough, UK).

${ }^{3}$ Formaldehyde-treated soybean meal (Trouw UK Ltd., Cheshire, UK).

${ }^{4}$ Ewe mineral-vitamin premix (SC Feeds, Staffordshire, UK). Major minerals $(\mathrm{g} / \mathrm{kg}$ ) were Ca 245.7, Na 78.6, Mg 50, and P 20. Trace minerals (mg/kg) were Zn 4,000, Fe 4,000, Mn 2,000, I 300, Co 80, and Se 24. Vitamins (IU/kg) were vitamin A 250,000 , vitamin $D_{3}$ 50,000 , and vitamin E 4,000.

${ }^{5} \mathrm{ND}=$ not determined.

meal, and haylage and were fed at 1 of 2 restricted levels of intake: high energy intake (high), to supply approximately $6.7 \mathrm{Mcal} / \mathrm{d}$ of ME per ewe, or low energy intake (low), predicted to supply 5.0 Mcal/d of ME per ewe (Table 1). The 2 diets were fed as a complete, rough mix with a concentrate-to-forage ratio of 0.65:0.35 (DM basis). The CP content was altered to ensure that the predicted MP intake, calculated according to the Agricultural and Food Research Council (1995), was similar for ewes on either feeding level (approximately 230 $\mathrm{g} / \mathrm{d})$. Each of the diets was either unsupplemented 
(-CLA) or supplemented (+CLA) with a lipid-encapsulated CLA supplement (BASF AG, Ludwigshafen, Germany) at the daily rate of $25 \mathrm{~g} / \mathrm{ewe}$. This level was chosen because it was the same as that used by Lock et al. (2006), where it was reported to reduce milk fat content by $23 \%$ and was predicted to result in the desired CN:fat ratio of approximately 0.7. To ensure a similar dietary energy supply, the unsupplemented ewes received $25 \mathrm{~g} / \mathrm{d}$ of a calcium soap of fatty acids (CSFA; Megalac, Volac UK Ltd., Royston, UK). Supplementation of lactating ewe diets with CSFA, compared with no fat supplementation, had little effect on milk yield, but was associated with an increase in milk fat content and yield and a reduction in the proportion of short- and medium-chain fatty acids (Gargouri et al., 2006). The incremental amount of CSFA used here (25 $\mathrm{g} / \mathrm{d})$ was considerably lower than that associated with the maximal milk fat response $(190 \mathrm{~g} / \mathrm{d})$ and acted as a replacement for the lipid-encapsulated CLA rather than as a true supplement.

The diets were provided in each of four 21-d periods in a $4 \times 4$ Latin square design, with a 16 -d adaptation to the diets and $5 \mathrm{~d}$ of sample collection. Fresh feed was offered daily, and feed samples were taken and stored at $-20^{\circ} \mathrm{C}$ over the final $5 \mathrm{~d}$ of each period. During the final $5 \mathrm{~d}$, milk yield was recorded at each milking and individual samples were taken for fat, protein, and lactose determination. On the final day of each period, an additional milk sample was collected at each milking and stored at $-20^{\circ} \mathrm{C}$ for fatty acid analysis. On d 20 of each period, blood was sampled from the jugular vein 3 times $(0730,1130$, and $1430 \mathrm{~h})$ into evacuated tubes containing potassium oxalate, and the plasma was separated and frozen at $-20^{\circ} \mathrm{C}$ for subsequent analysis of BHBA and glucose. Ewes were weighed and BCS was determined at the beginning of the experiment and end of each period.

\section{Cheese Production}

Total milk production over the final $5 \mathrm{~d}$ of each period was collected and stored at $-20^{\circ} \mathrm{C}$ prior to being made into a variant of Queso Manchego, as described by Scott (1981). Freezing ewe's milk for up to 6 mo was shown to have little effect on subsequent cheese yield or composition (Zhang et al., 2006). Before cheese making, the milk was thawed at $5^{\circ} \mathrm{C}$ over a 48 -h period. Approximately $30 \mathrm{~kg}$ of the unpasteurized milk was heated to 30 to $32^{\circ} \mathrm{C}$ in a stainless-steel container, and starter (Lactococcus lactis ssp. lactis, Lactococcus lactis ssp. cremoris, and Streptococcus salivarius ssp. thermophilus; EZAL Dried RA 026, Danisco, Wellingborough, UK) was added at the rate of $2.1 \mathrm{~g} / 100 \mathrm{~kg}$ of milk. The milk was ripened for $50 \mathrm{~min}$, and chymosin (Albamax,
Caglificio Clerici, Cadorago, Italy) was added as a clotting agent at the rate of $0.24 \mathrm{~mL} / \mathrm{kg}$ of milk. The curd was allowed to set over 30 to $45 \mathrm{~min}$ before being cut into 1 - to $2-\mathrm{cm}$ cubes and was left for $10 \mathrm{~min}$ before being cut again into 2 - to 3 -mm pieces over $20 \mathrm{~min}$. The curd was stirred for $10 \mathrm{~min}$, and the temperature was raised to 38 to $40^{\circ} \mathrm{C}$ over $30 \mathrm{~min}$ with stirring, the whey was drained off, the curd was weighed, and salt was added at $2.5 \%$ of the fresh weight. The curd was then transferred to molds overnight and stored at 12 to $14^{\circ} \mathrm{C}$, 85 to $90 \%$ relative humidity, for $3 \mathrm{~d}$; the surface was oiled with virgin olive oil, and the cheese was matured under the same conditions for $90 \mathrm{~d}$.

Sensory assessment was modified from that described by Hunter and McEwan (1998). Briefly, 1-cmthick samples were removed from the matured cheese and trimmed of all external surfaces and maintained at $12^{\circ} \mathrm{C}$. Sections were cut from the subsamples and served to a panel of 10 trained sensory assessors with previous experience in cheese tasting. The assessors tasted 4 samples of cheeses in balanced order in each of 4 sessions, and the sensory attributes of odor, appearance, texture, flavor, and several previously agreed flavor descriptive terms, including overall appeal, were rated on $10-\mathrm{cm}$ unstructured line scales in which $0=$ nil and $10=$ extreme (Table 2 ).

\section{Chemical Analysis}

Feed samples and milk samples were analyzed as described by Lock et al. (2006). In addition, bulk milk samples were analyzed for CN (method 998.50; AOAC, 2000) and true protein (Johnson et al., 2001). Cheese samples were analyzed using AOAC (2000) methods for DM (948.12), fat (933.05), and protein (988.05). Feed fatty acids were extracted and methylated by the procedure of Sukhija and Palmquist (1988) using chloroform, with nonadecaenoic acid as the internal standard. Milk and cheese samples were analyzed for fatty acids as described by Lock et al. (2006). Fatty acid identification and recoveries were determined using pure methyl ester standards (Nu-Chek Prep, Elysian, MN; Natural ASA, Hovdebygda, Norway). A butter oil reference standard (CRM 164; Commission of the European Community Bureau of References, Brussels, Belgium) was used as a routine check for recoveries and correction factors for individual fatty acids. Plasma samples were analyzed for BHBA (Randox Laboratories, Crumlin, County Antrim, UK; kit catalog no. RB 1008) and glucose (Randox Laboratories; kit catalog no. GL 1611) using a Cobas Miras Plus autoanalyzer (ABX Diagnostics, Bedfordshire, UK). 
Table 2. Definitions and scaling magnitudes used for the sensory evaluation of the experimental cheese

\begin{tabular}{|c|c|c|c|}
\hline Attribute & Description & 0 & 10 \\
\hline Odor intensity & Strength of odor & Nil & Extreme \\
\hline \multicolumn{4}{|l|}{ Appearance } \\
\hline Waxy & Appearance resembling wax consistency & Nil & Extreme \\
\hline Rubberiness on touch & Amount of springiness when pressed with finger & Nil & Extreme \\
\hline \multicolumn{4}{|l|}{ Texture on cutting } \\
\hline Rubberiness & Amount of springiness in sample on eating & Nil & Extreme \\
\hline Moistness & Perceived degree of water in sample during chewing & Very dry & Very moist \\
\hline Smoothness & Degree to which sample melts in the mouth & Nil & Extreme \\
\hline Grainy & Amount of small particles in the sample & Nil & Extreme \\
\hline \multicolumn{4}{|c|}{ (1) } \\
\hline Salty & Taste associated with salt & Nil & Extreme \\
\hline Sour & Taste associated with acids & Nil & Extreme \\
\hline Sweet & Taste associated with sugar & Nil & Extreme \\
\hline Musty & Taste associated with stale, old, fusty, or moldy & Nil & Extreme \\
\hline Tangy/pungent/burning & Sharp astringent flavor causing a drying feeling in the mouth & Nil & Extreme \\
\hline \multicolumn{4}{|c|}{ 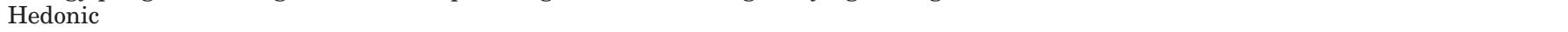 } \\
\hline Overall liking & End point & Nil & Extreme \\
\hline
\end{tabular}

\section{Statistical Analyses}

Live weight and BCS change were determined as the initial minus the final value for each period divided by $21 \mathrm{~d}$. Data were analyzed as a Latin square design using Genstat 9.1 (VSN Int. Ltd., Oxford, UK). The model used was

$$
\mathrm{Y}_{\mathrm{ijk}}=\mu+\mathrm{T}_{\mathrm{i}}+\mathrm{P}_{\mathrm{j}}+\mathrm{A}_{\mathrm{k}}+\mathrm{E}_{\mathrm{ijk}}
$$

where $Y_{i j k}$ is observation, $\mu$ is the overall mean, $T_{i}$ is treatment, $\mathrm{P}_{\mathrm{j}}$ is period, $\mathrm{A}_{\mathrm{k}}$ is animal, and $\mathrm{E}_{\mathrm{ijk}}$ is the residual error. Treatment degrees of freedom were further split into main effects of feeding level (L), CLA supplement (F), and their interaction (Int). For most variables, the interaction was not significant and only the main effects of feeding level and CLA supplementation are presented.

\section{RESULTS}

Ewes receiving the low feeding level had a DMI that was $79 \%$ of those on high $(P<0.001$; Table 3$)$. There was no effect $(P>0.05)$ of treatment on milk yield, which averaged $1,215 \mathrm{~g} / \mathrm{d}$. By contrast, milk fat percentage was $23 \%$ lower $(P<0.001)$ and milk fat yield $(\mathrm{g} / \mathrm{d})$ was reduced by $20 \%(P<0.001)$ in + CLA. Milk protein percentage was $2.6 \%$ less $(P=0.020)$ in + CLA and was
$3.5 \%$ greater $(P=0.003)$ in ewes fed low vs. high. Milk protein yield was greater $(P=0.05)$ in ewes fed low compared with high, but there was no effect $(P>0.05)$ of CLA supplementation. There was a small decrease $(P=0.019)$ in milk lactose concentration $(\mathrm{g} / \mathrm{kg})$ in + CLA compared with -CLA animals, but there was no effect $(P>0.05)$ of treatment on lactose yield. There was no effect of treatment on BCS or BCS change $(P>0.05)$, but BW and daily BW gain were both higher $(P<0.001)$ in ewes fed high compared with low (66.2 vs. $64.8 \mathrm{~kg}$ and 0.13 vs. $0.05 \mathrm{~kg} / \mathrm{d}$ for high and low, respectively). Similarly, the calculated energy balance was greater $(P<0.001)$ in ewes fed high or +CLA. There was no effect $(P>0.05)$ of treatment on plasma BHBA levels, but plasma glucose levels were decreased $(P<0.01)$ in +CLA compared with -CLA animals, or those fed high compared with low although the difference between treatment was numerically small.

There was no effect $(P>0.05)$ of treatment on milk true protein or CN concentration $(42.3$ and $33.8 \mathrm{~g} / \mathrm{kg}$, respectively), or in the CN:true protein ratio (0.80; Table 4). By contrast, the CN:fat ratio was increased ( $P$ $<0.001)$ in milk from +CLA (0.70 and 0.54 for +CLA and -CLA, respectively). Cheese yield was similar among treatments when measured on $d 1$, but was greatest on d 90 when made from milk of ewes receiving high and - CLA $(P<0.05$ for the interaction). 
Table 3. Performance and plasma metabolite concentrations in ewes fed diets at a high or low level of feeding and either unsupplemented (-) or supplemented (+) with a lipid-encapsulated source containing trans-10, cis-12 conjugated linoleic acid (CLA)

\begin{tabular}{|c|c|c|c|c|c|c|c|}
\hline \multirow[b]{3}{*}{ Item } & \multicolumn{4}{|c|}{ Treatment } & \multirow[b]{3}{*}{ SEM } & \multirow{2}{*}{\multicolumn{2}{|c|}{ Significance $^{1}$}} \\
\hline & \multicolumn{2}{|c|}{ High feeding level } & \multicolumn{2}{|c|}{ Low feeding level } & & & \\
\hline & -CLA & $+\mathrm{CLA}$ & -CLA & $+\mathrm{CLA}$ & & $\mathrm{L}$ & $\mathrm{F}$ \\
\hline Intake, $\mathrm{kg}$ of $\mathrm{DM} / \mathrm{d}$ & 2.10 & 2.08 & 1.66 & 1.66 & 0.018 & $<0.001$ & 0.463 \\
\hline Milk yield, g/d & 1,188 & 1,225 & 1,204 & 1,244 & 40.4 & 0.664 & 0.347 \\
\hline \multicolumn{8}{|l|}{ Milk fat } \\
\hline$\%$ & 6.36 & 4.87 & 6.17 & 4.79 & 0.093 & 0.148 & $<0.001$ \\
\hline $\mathrm{g} / \mathrm{d}$ & 75.2 & 59.1 & 73.8 & 59.9 & 2.12 & 0.889 & $<0.001$ \\
\hline \multicolumn{8}{|l|}{ Milk protein } \\
\hline$\%$ & 4.69 & 4.52 & 4.80 & 4.73 & 0.049 & 0.003 & 0.020 \\
\hline $\mathrm{g} / \mathrm{d}$ & 54.8 & 55.1 & 57.2 & 58.6 & 1.45 & 0.050 & 0.575 \\
\hline \multicolumn{8}{|l|}{ Milk lactose } \\
\hline$\%$ & 4.65 & 4.59 & 4.65 & 4.59 & 0.023 & 0.911 & 0.019 \\
\hline $\mathrm{g} / \mathrm{d}$ & 55.3 & 56.4 & 56.0 & 57.4 & 1.81 & 0.617 & 0.502 \\
\hline BW, kg & 66.4 & 65.9 & 64.9 & 64.7 & 0.40 & $<0.001$ & 0.434 \\
\hline BW change, kg/d & 0.13 & 0.13 & 0.03 & 0.07 & 0.021 & $<0.001$ & 0.523 \\
\hline $\mathrm{BCS}^{2}$ & 2.07 & 2.00 & 2.08 & 2.11 & 0.044 & 0.179 & 0.670 \\
\hline BCS change, units/d & 0.001 & -0.005 & 0.004 & 0.001 & 0.003 & 0.138 & 0.146 \\
\hline Energy balance, ${ }^{3} \mathrm{Mcal} / \mathrm{d}$ & 1.3 & 1.5 & 0.2 & 0.4 & 0.06 & $<0.001$ & $<0.001$ \\
\hline \multicolumn{8}{|c|}{ Mean plasma concentrations } \\
\hline Glucose, $\mathrm{mmol} / \mathrm{L}$ & 3.33 & 3.27 & 3.61 & 3.41 & 0.038 & $<0.001$ & 0.002 \\
\hline BHBA, mmol/L & 0.53 & 0.55 & 0.56 & 0.53 & 0.022 & 0.991 & 0.744 \\
\hline
\end{tabular}

${ }^{1} P$-values; $\mathrm{L}=$ main effect of level of feeding; $\mathrm{F}=$ main effect of fat source.

${ }^{2}$ Scale 0 (thin) to 5 (fat) (Russell et al., 1969).

${ }^{3}$ Calculated according to the Agricultural and Food Research Council (1995) as ME intake (adjusted for feeding level) - (maintenance energy requirements + milk energy output).

Supplementation with CLA reduced the proportion of fatty acids of chain length $<\mathrm{C}_{16}(P<0.001)$ and generally increased those $>\mathrm{C}_{16}(P<0.001)$, whereas high feeding, compared with low feeding, generally reduced the proportion of milk fatty acids of chain length $>\mathrm{C}_{16}$, particularly 18:1 cis-9 and 18:1 trans-11 $(P<0.001)$, and increased 16:0 $(P<0.001$; Table 5$)$. Fatty acid ratios in milk constituting the desaturase index were reduced $(P<0.001)$ by + CLA but were unaffected $(P>0.05)$ by the feeding level. There was no effect $(P>0.05)$ of treatment on the chemical composition of the cheese except for moisture content, which was greater $(P<$ $0.05)$ in samples made with milk from +CLA-fed ewes (Table 6). The cheese fatty acid profile was very similar to that of the milk (Tables 5 and 6).

Supplementation with CLA resulted in a less yellow cheese $(P<0.001)$ that was moister $(P<0.05)$, creamier $(P<0.001)$, and less oily $(P<0.05$; Table 7$)$. Cheese made from the milk of ewes fed the high feeding was rated as less yellow $(P<0.001)$, less salty $(P<0.05)$,

Table 4. Milk composition and cheese yield from ewes fed diets at a high or low level of feeding and either unsupplemented (-) or supplemented (+) with a lipid-encapsulated source containing trans-10, cis12 conjugated linoleic acid (CLA) ${ }^{1}$

\begin{tabular}{|c|c|c|c|c|c|c|c|c|}
\hline \multirow[b]{3}{*}{ Item } & \multicolumn{4}{|c|}{ Treatment } & \multirow[b]{3}{*}{ SEM } & & & \\
\hline & \multicolumn{2}{|c|}{ High feeding level } & \multicolumn{2}{|c|}{ Low feeding level } & & \multicolumn{3}{|c|}{ Significance $^{2}$} \\
\hline & -CLA & + CLA & -CLA & + CLA & & $\mathrm{L}$ & $\mathrm{F}$ & Int \\
\hline $\mathrm{CN}, \mathrm{g} / \mathrm{kg}$ & 33.9 & 33.0 & 34.3 & 34.2 & 1.55 & 0.624 & 0.760 & 0.772 \\
\hline True protein, $\mathrm{g} / \mathrm{kg}$ & 42.9 & 40.6 & 43.8 & 41.9 & 1.21 & 0.372 & 0.119 & 0.896 \\
\hline CN:true protein & 0.79 & 0.81 & 0.78 & 0.82 & 0.024 & 0.844 & 0.248 & 0.703 \\
\hline CN:fat & 0.53 & 0.68 & 0.55 & 0.71 & 0.027 & 0.348 & $<0.001$ & 0.819 \\
\hline \multicolumn{9}{|l|}{ Cheese vield, $\mathrm{kg} / \mathrm{kg}$} \\
\hline d 1 & 0.164 & 0.156 & 0.151 & 0.162 & 0.0073 & 0.661 & 0.851 & 0.281 \\
\hline d 90 & 0.121 & 0.111 & 0.111 & 0.113 & 0.0018 & 0.116 & 0.113 & 0.038 \\
\hline
\end{tabular}

${ }^{1}$ Values from samples bulked within d 17 to 21 of each period.

${ }^{2} P$-values; $\mathrm{L}=$ main effect of level of feeding, $\mathrm{F}=$ main effect of fat source, $\mathrm{Int}=$ interaction between feeding level and fat source. 
Table 5. Fatty acid composition of milk from ewes fed diets at a high or low level of feeding and either unsupplemented (-) or supplemented (+) with a lipid-encapsulated source containing trans-10, cis-12 conjugated linoleic acid (CLA)

\begin{tabular}{|c|c|c|c|c|c|c|c|}
\hline \multirow[b]{3}{*}{ Item } & \multicolumn{4}{|c|}{ Treatment } & \multirow[b]{3}{*}{ SEM } & \multirow{2}{*}{\multicolumn{2}{|c|}{ Significance $^{1}$}} \\
\hline & \multicolumn{2}{|c|}{ High feeding level } & \multicolumn{2}{|c|}{ Low feeding level } & & & \\
\hline & -CLA & $+\mathrm{CLA}$ & -CLA & $+\mathrm{CLA}$ & & $\mathrm{L}$ & $\mathrm{F}$ \\
\hline \multicolumn{8}{|l|}{ Fatty acid ${ }^{2}$} \\
\hline $4: 0$ & 4.15 & 4.20 & 4.29 & 4.11 & 0.065 & 0.788 & 0.317 \\
\hline $6: 0$ & 1.74 & 1.22 & 1.81 & 1.18 & 0.064 & 0.825 & $<0.001$ \\
\hline 8:0 & 1.18 & 0.75 & 1.26 & 0.73 & 0.066 & 0.622 & $<0.001$ \\
\hline $10: 0$ & 3.24 & 2.15 & 3.46 & 2.09 & 0.204 & 0.697 & $<0.001$ \\
\hline $12: 0$ & 1.97 & 1.70 & 2.10 & 1.67 & 0.103 & 0.630 & 0.002 \\
\hline $14: 0$ & 7.10 & 7.16 & 6.92 & 6.80 & 0.171 & 0.125 & 0.833 \\
\hline $14: 1$ cis -9 & 0.12 & 0.08 & 0.12 & 0.07 & 0.005 & 0.433 & $<0.001$ \\
\hline $15: 0$ & 0.66 & 0.65 & 0.65 & 0.67 & 0.013 & 0.467 & 0.640 \\
\hline $16: 0$ & 35.7 & 36.5 & 33.6 & 33.8 & 0.31 & $<0.001$ & 0.161 \\
\hline $16: 1$ cis -9 & 1.30 & 1.06 & 1.30 & 1.04 & 0.027 & 0.594 & $<0.001$ \\
\hline $17: 0$ & 0.33 & 0.36 & 0.35 & 0.39 & 0.005 & $<0.001$ & $<0.001$ \\
\hline $18: 0$ & 6.84 & 8.99 & 6.97 & 9.91 & 0.247 & 0.041 & $<0.001$ \\
\hline $18: 1$ trans -6 to 8 & 0.45 & 0.47 & 0.41 & 0.45 & 0.020 & 0.135 & 0.098 \\
\hline 18:1 trans -9 & 0.49 & 0.48 & 0.47 & 0.47 & 0.013 & 0.393 & 0.633 \\
\hline 18:1 trans -10 & 0.76 & 0.86 & 0.74 & 0.87 & 0.044 & 0.997 & 0.011 \\
\hline 18:1 trans -11 & 1.68 & 2.01 & 1.99 & 2.53 & 0.105 & $<0.001$ & $<0.001$ \\
\hline 18:1 trans -12 & 0.45 & 0.47 & 0.41 & 0.45 & 0.014 & 0.032 & 0.072 \\
\hline $18: 1$ cis -9 & 25.5 & 24.6 & 26.5 & 25.9 & 0.295 & $<0.001$ & 0.021 \\
\hline $18: 2$ cis $-9, c i s-12$ & 2.91 & 2.79 & 2.97 & 2.98 & 0.073 & 0.101 & 0.461 \\
\hline $18: 2$ cis -9, trans $-11^{3}$ & 0.85 & 0.87 & 1.10 & 1.12 & 0.037 & $<0.001$ & 0.387 \\
\hline $18: 2$ trans -10, cis $-12^{3,4}$ & 0.01 & 0.11 & 0.01 & 0.13 & 0.005 & 0.032 & $<0.001$ \\
\hline $18: 3$ cis -9, cis -12, cis -15 & 0.18 & 0.17 & 0.19 & 0.19 & 0.008 & 0.067 & 0.268 \\
\hline $20: 0$ & 0.14 & 0.16 & 0.13 & 0.16 & 0.004 & 0.853 & $<0.001$ \\
\hline Other & 2.22 & 2.18 & 2.31 & 2.36 & 0.041 & 0.003 & 0.844 \\
\hline \multicolumn{8}{|l|}{ Summation } \\
\hline$<\mathrm{C}_{16}$ & 20.2 & 17.9 & 20.6 & 17.3 & 0.575 & 0.905 & $<0.001$ \\
\hline $\mathrm{C}_{16}+16: 1$ & 37.0 & 37.5 & 34.9 & 34.8 & 0.306 & $<0.001$ & 0.539 \\
\hline$>\mathrm{C}_{16}$ & 42.8 & 44.6 & 44.5 & 47.9 & 0.448 & $<0.001$ & $<0.001$ \\
\hline \multicolumn{8}{|l|}{ Desaturase index 5} \\
\hline $14: 1 /(14: 0+14: 1)$ & 0.016 & 0.011 & 0.017 & 0.011 & 0.0005 & 0.883 & $<0.001$ \\
\hline $16: 1 /(16: 0+16: 1)$ & 0.035 & 0.028 & 0.037 & 0.030 & 0.0009 & 0.058 & $<0.001$ \\
\hline $18: 1 /(18: 0+18: 1)$ & 0.79 & 0.73 & 0.79 & 0.72 & 0.006 & 0.747 & $<0.001$ \\
\hline$c 9, t 11$ CLA $/(18: 1 t 11+c 9, t 11$ CLA $)$ & 0.34 & 0.31 & 0.36 & 0.31 & 0.007 & 0.164 & $<0.001$ \\
\hline
\end{tabular}

${ }^{1} P$-values; $\mathrm{L}=$ main effect of level of feeding, $\mathrm{F}=$ main effect of fat source.

${ }^{2}$ Values represent milk fatty acid profile on d 21 of each period.

${ }^{3}$ Milk fat contains a number of additional isomers of CLA (cis/trans, cis/cis, and trans/trans) and these coelute under the analytical conditions used in the present study.

${ }^{4}$ Interaction between feed level and CLA supplementation $(P=0.028)$.

${ }^{5}$ Unless otherwise indicated, double bonds are $c i s-9 ; c$ and $t=c i s$ and trans, respectively.

and more sour $(P<0.05)$ than those fed the low feeding. There was an interaction between feed level and CLA supplementation on rubberiness texture on eating, which was increased with +CLA when ewes received high and not low $(P<0.01)$. Overall hedonic liking was greater $(P=0.05)$ for cheese made from the milk of + CLA-fed ewes.

\section{DISCUSSION}

One of the objectives of the current study was to investigate the effect of supplementation with a ruminally protected source of trans-10, cis-12 CLA on milk performance of dairy ewes when fed at a restricted en- ergy supply that is characteristic of early lactation. The observation that milk fat content was reduced by 23 and $22 \%$ because of +CLA at the high and low feeding level, respectively, is similar to the $23 \%$ reduction previously reported in ewes fed ad libitum (Lock et al., 2006). Likewise, the $20 \%$ reduction in milk fat yield is comparable to the $16 \%$ observed in our previous sheep study. This decrease in fat yield is comparable to the 20 to $25 \%$ reduction reported in dairy cows fed lipidencapsulated CLA supplements at a similar dose (Perfield et al., 2004; de Veth et al., 2006). de Veth et al. (2004) summarized 7 studies involving abomasal infusion of trans-10, cis-12 CLA to dairy cows and developed an equation to describe the relationship between the 
Table 6. Chemical and fatty acid composition of cheese made from ewes fed diets at a high or low level of feeding and either unsupplemented (-) or supplemented (+) with a lipid-encapsulated source containing trans-10, cis-12 conjugated linoleic acid (CLA)

\begin{tabular}{|c|c|c|c|c|c|c|c|}
\hline \multirow[b]{3}{*}{ Item } & \multicolumn{4}{|c|}{ Treatment } & \multirow[b]{3}{*}{ SEM } & \multirow{2}{*}{\multicolumn{2}{|c|}{ Significance $^{1}$}} \\
\hline & \multicolumn{2}{|c|}{ High feeding level } & \multicolumn{2}{|c|}{ Low feeding level } & & & \\
\hline & -CLA & $+\mathrm{CLA}$ & -CLA & $+\mathrm{CLA}$ & & $\mathrm{L}$ & $\mathrm{F}$ \\
\hline Moisture, \% & 31.4 & 33.7 & 32.9 & 33.3 & 0.54 & 0.323 & 0.025 \\
\hline Fat, \% & 31.9 & 30.2 & 29.9 & 30.6 & 0.55 & 0.176 & 0.370 \\
\hline Protein, \% & 27.3 & 28.4 & 28.0 & 28.0 & 0.36 & 0.641 & 0.135 \\
\hline & 46.6 & 45.5 & 44.5 & 45.9 & 0.60 & 0.199 & 0.768 \\
\hline \multicolumn{8}{|l|}{ Fatty acid } \\
\hline $4: 0$ & 4.28 & 4.16 & 4.31 & 4.00 & 0.121 & 0.605 & 0.118 \\
\hline $6: 0$ & 1.75 & 1.25 & 1.84 & 1.32 & 0.081 & 0.326 & $<0.001$ \\
\hline $8: 0$ & 1.16 & 0.78 & 1.27 & 0.86 & 0.058 & 0.134 & $<0.001$ \\
\hline $10: 0$ & 3.16 & 2.22 & 3.44 & 2.55 & 0.151 & 0.077 & $<0.001$ \\
\hline $12: 0$ & 1.92 & 1.74 & 2.05 & 1.89 & 0.069 & 0.081 & 0.033 \\
\hline $14: 0$ & 6.99 & 7.30 & 6.93 & 7.14 & 0.256 & 0.677 & 0.345 \\
\hline $14: 1$ cis -9 & 0.12 & 0.09 & 0.11 & 0.07 & 0.010 & 0.329 & 0.006 \\
\hline $15: 0$ & 0.66 & 0.68 & 0.65 & 0.68 & 0.006 & 1.000 & 0.002 \\
\hline $16: 0$ & 36.4 & 36.4 & 34.0 & 34.0 & 0.19 & $<0.001$ & 0.880 \\
\hline $16: 1$ cis -9 & 1.24 & 1.04 & 1.26 & 1.02 & 0.045 & 0.978 & $<0.001$ \\
\hline $17: 0$ & 0.32 & 0.37 & 0.35 & 0.39 & 0.005 & $<0.001$ & $<0.001$ \\
\hline $18: 0$ & 7.34 & 8.95 & 7.46 & 9.76 & 0.259 & 0.105 & $<0.001$ \\
\hline $18: 1$ trans -6 to 8 & 0.44 & 0.48 & 0.41 & 0.46 & 0.024 & 0.277 & 0.107 \\
\hline $18: 1$ trans -9 & 0.52 & 0.49 & 0.47 & 0.49 & 0.012 & 0.057 & 0.616 \\
\hline $18: 1$ trans -10 & 0.75 & 0.89 & 0.67 & 0.92 & 0.042 & 0.568 & $<0.001$ \\
\hline 18:1 trans -11 & 1.70 & 2.11 & 2.12 & 2.61 & 0.113 & 0.003 & 0.003 \\
\hline 18:1 trans -12 & 0.43 & 0.47 & 0.40 & 0.44 & 0.014 & 0.109 & 0.026 \\
\hline $18: 1$ cis -9 & 24.9 & 24.3 & 26.0 & 24.7 & 0.269 & 0.022 & 0.006 \\
\hline $18: 2$ cis $-9, c i s-12$ & 2.86 & 2.82 & 2.82 & 2.89 & 0.044 & 0.782 & 0.659 \\
\hline $18: 2$ cis -9, trans $-11^{3}$ & 0.77 & 0.92 & 1.07 & 1.13 & 0.033 & $<0.001$ & 0.013 \\
\hline 18:2 trans -10, cis $-12^{3}$ & $<0.01$ & 0.11 & 0.01 & 0.11 & 0.007 & 0.293 & $<0.001$ \\
\hline $18: 3$ cis -9, cis -12, cis -15 & 0.23 & 0.21 & 0.19 & 0.20 & 0.011 & 0.059 & 0.447 \\
\hline $20: 0$ & 0.13 & 0.15 & 0.13 & 0.15 & 0.005 & 0.206 & 0.003 \\
\hline Other & 1.99 & 2.14 & 2.10 & 2.21 & 0.065 & 0.182 & 0.074 \\
\hline \multicolumn{8}{|l|}{ Summation } \\
\hline$<\mathrm{C}_{16}$ & 20.0 & 18.2 & 20.6 & 18.5 & 0.628 & 0.505 & 0.013 \\
\hline $\mathrm{C}_{16}+16: 1$ & 37.6 & 37.4 & 35.3 & 35.0 & 0.167 & $<0.001$ & 0.280 \\
\hline$>\mathrm{C}_{16}$ & 42.4 & 44.4 & 44.1 & 46.4 & 0.496 & 0.004 & 0.002 \\
\hline
\end{tabular}

${ }^{1} P$-values; $\mathrm{L}=$ main effect of level of feeding, $\mathrm{F}=$ main effect of fat source.

${ }^{2} \mathrm{FDM}=$ fat in DM.

${ }^{3}$ Milk fat contains a number of additional isomers of CLA (cis/trans, cis/cis, and trans/trans) and these coelute under the analytical conditions used in the present study.

increase in milk fat content of trans-10, cis-12 CLA and the reduction in milk fat yield. Based on this equation, the milk fat content of trans-10, cis-12 CLA in +CLAfed ewes observed in the current study corresponds to a predicted $25 \%$ reduction in milk fat yield; the similarity of the observed and predicted values provides support that dairy sheep and dairy cows respond similarly to trans-10, cis-12 CLA supplementation when doses are compared on a metabolic BW basis.

Milk and milk protein yield were unaffected by CLA supplementation, a finding that contrasts with previous observations that milk and milk protein yield were increased by 10 and 7\%, respectively (Lock et al., 2006). Despite the decreased milk fat output, there was no effect of CLA supplementation on BW gain or BCS. In dairy cows, decreases in milk fat synthesis were reported, but there was no significant effect on milk yield or BW following CLA supplementation (Selberg et al., 2004). Supplementation with CLA resulted in a greater calculated energy balance (energy consumed energy secreted in milk) of $0.2 \mathrm{Mcal} / \mathrm{d}$. This difference equates to a predicted increase in BW of $0.02 \mathrm{~kg} / \mathrm{d}$, a value similar in magnitude to that observed (Table 3), but too small to be significant in the short-term changeover design used here.

Similar to the effects of CLA, increasing the feeding rate from low to high was associated with an increase in body energy balance rather than in milk or milk protein yield. In lactating ruminants, milk yield is generally positively and milk fat content negatively related to dietary energy intake. Despite this, Cannas et al. (1998) reported a reduced milk yield when a higher 
Table 7. Sensory attribute ratings of cheeses made from ewes fed diets at a high or low level of feeding and either unsupplemented (-) or supplemented (+) with a lipid-encapsulated source containing trans-10, cis-12 conjugated linoleic acid (CLA)

\begin{tabular}{|c|c|c|c|c|c|c|c|}
\hline \multirow[b]{3}{*}{ Item } & \multicolumn{4}{|c|}{ Treatment } & \multirow[b]{3}{*}{ SEM } & \multirow{2}{*}{\multicolumn{2}{|c|}{ Significance $^{1}$}} \\
\hline & \multicolumn{2}{|c|}{ High feeding level } & \multicolumn{2}{|c|}{ Low feeding level } & & & \\
\hline & -CLA & + CLA & -CLA & +CLA & & $\mathrm{L}$ & $\mathrm{F}$ \\
\hline Odor intensity & 3.59 & 3.60 & 3.64 & 3.69 & 0.245 & 0.775 & 0.895 \\
\hline \multicolumn{8}{|l|}{ Appearance } \\
\hline Yellowness & 3.09 & 2.57 & 4.50 & 3.98 & 0.152 & $<0.001$ & $<0.001$ \\
\hline Waxy & 1.85 & 1.50 & 2.01 & 1.97 & 0.166 & 0.060 & 0.240 \\
\hline Rubberiness & 1.10 & 1.20 & 1.48 & 1.33 & 0.184 & 0.172 & 0.903 \\
\hline Texture on cutting & 6.56 & 6.45 & 6.60 & 6.57 & 0.261 & 0.767 & 0.796 \\
\hline \multicolumn{8}{|l|}{ Texture on eating } \\
\hline Crumbliness & 5.34 & 4.86 & 4.49 & 4.93 & 0.295 & 0.190 & 0.949 \\
\hline Rubberiness & 0.82 & 1.33 & 1.28 & 1.00 & 0.135 & 0.586 & 0.391 \\
\hline Moistness & 2.27 & 2.55 & 2.06 & 2.62 & 0.176 & 0.691 & 0.017 \\
\hline Smoothness & 2.76 & 3.33 & 2.99 & 3.12 & 0.237 & 0.983 & 0.139 \\
\hline Grainy & 2.89 & 2.33 & 2.56 & 2.31 & 0.244 & 0.481 & 0.097 \\
\hline \multicolumn{8}{|l|}{ Flavor } \\
\hline Flavor strength & 4.53 & 4.42 & 4.82 & 4.39 & 0.249 & 0.602 & 0.280 \\
\hline Creaminess & 1.36 & 1.88 & 1.42 & 2.29 & 0.214 & 0.270 & $<0.001$ \\
\hline Oily & 1.46 & 0.80 & 1.20 & 0.86 & 0.234 & 0.670 & 0.034 \\
\hline Fruity & 1.50 & 1.64 & 1.64 & 1.87 & 0.196 & 0.335 & 0.348 \\
\hline Nutty & 1.48 & 1.20 & 1.52 & 1.50 & 0.204 & 0.399 & 0.448 \\
\hline Salty & 1.75 & 1.98 & 2.44 & 2.16 & 0.216 & 0.048 & 0.913 \\
\hline Sour & 1.42 & 1.49 & 0.96 & 1.17 & 0.184 & 0.038 & 0.453 \\
\hline Sweet & 1.15 & 0.79 & 0.92 & 0.84 & 0.153 & 0.542 & 0.147 \\
\hline Musty & 1.08 & 0.96 & 0.91 & 0.79 & 0.193 & 0.386 & 0.526 \\
\hline Tangy & 1.46 & 1.41 & 1.46 & 1.46 & 0.228 & 0.913 & 0.913 \\
\hline Hedonic overall liking & 3.79 & 4.49 & 4.08 & 4.56 & 0.300 & 0.555 & 0.050 \\
\hline
\end{tabular}

${ }^{1} P$-values; $\mathrm{L}=$ main effect of level of feeding, $\mathrm{F}=$ main effect of fat source.

energy, less fibrous diet was fed to dairy ewes, and suggested that stimulation of tissue nutrient uptake and increased fat deposition were responsible. Stage of lactation may be one explanation for the positive energy balance of the ewes in the current study, because animals were 17 wk into lactation by the end of the experiment. Alternatively, the milk removal rate may have been insufficient to necessitate body energy mobilization. For example, ewes that were machine milked produced $36 \%$ less milk and were in positive energy balance when compared with twin-suckled ewes that were in negative energy balance (Partington et al., 2004).

Milk concentration of trans-10, cis-12 CLA was increased substantially by +CLA, with a calculated transfer efficiency of $2.6 \pm 0.24 \%$ and $2.4 \pm 0.21 \%$ (mean \pm $\mathrm{SD})$ for low and high, respectively. These values are less than the $3.8 \%$ reported in lactating ewes when fed the same supplement (Lock et al., 2006), but at the low end of the range (2.6 to $7.9 \%$ ) reported when lipidencapsulated CLA supplements were fed to dairy cows (Perfield et al., 2004; de Veth et al., 2006). The majority of studies that have supplemented the diets of dairy cows or sheep with a protected source of CLA have reported an increase in milk fat content of cis-9, trans11 CLA (de Veth et al., 2006; Lock et al., 2006). It is of interest to note that there was no effect on milk cis-9, trans-11 CLA concentration in the current study. If the same transfer efficiency into milk is assumed for the lipid-encapsulated cis-9, trans-11 CLA as trans-10, cis12 CLA, then the supplement can be calculated to have contributed approximately $0.05 \mathrm{~g} / \mathrm{d}$ or $0.1 \mathrm{~g} / 100 \mathrm{~g}$ of milk fat, compared with the observed mean increase of $0.02 \mathrm{~g} / 100 \mathrm{~g}$. This finding may be explained by the reduced $\Delta^{9}$-desaturase indices in +CLA animals (Table 5 ), which were lower than that observed in a number of studies in sheep (Lock et al., 2006) or dairy cows (de Veth et al., 2006). Feeding studies with dairy cows have shown a positive relationship between trans-11 18:1 and cis-9, trans-11 CLA (Jiang et al., 1996), and the majority of the cis-9, trans-11 CLA found in milk fat originates from trans-11 18:1 and endogenous synthesis via the enzyme $\Delta^{9}$-desaturase (Bauman and Lock, 2006). Reasons for the comparatively large reduction in $\Delta^{9}$-desaturase indices in the current study are unclear; fasting produced a marked decrease in the activity of $\Delta^{9}$-desaturase (Gellhorn and Benjamin, 1964), but there was no effect of level of restriction in the current study. Trans-10, cis-12 inhibited both gene expression and $\Delta^{9}$-desaturase activity in dairy cows, but responses have generally been observed at higher doses of CLA than used here (reviewed in Bauman and Lock, 2006). 
In the current study, milk fat content of cis-9, trans11 CLA was $29 \%$ higher and trans-11 $18: 1$ was $22 \%$ higher in ewes when fed the low compared with the high feeding level. This finding is consistent with that of Jiang et al. (1996), who reported an increase in milk trans-11 18:1 and cis-9, trans-11 CLA levels when dairy cows were fed the same diet at a restricted level compared with ad libitum. Diet is the major factor affecting the milk fat content of $c i s-9$, trans-11 CLA in ruminants, and the impact of nutrition and dietary factors on milk fat CLA was summarized previously (Bauman and Lock, 2006).

A second objective was to examine the effect of +CLA and feeding level on cheese composition and sensory attributes. Initial cheese yield ( $\mathrm{kg}$ of cheese/ $\mathrm{kg}$ of milk) averaged 0.16 , a value comparable to that reported by Wendorff (2002). Cheese yield was not affected by dietary treatment despite the decrease in milk fat that occurred with +CLA; the basis for this relates to the improved milk CN:fat ratio attributable to +CLA. This finding is consistent with that of Haddadin et al. (1995), who reported little effect on sheep cheese yield when the $\mathrm{CN}$ :fat ratio increased from 0.5 to 0.7 . Moisture content decreased and fat and protein content increased marginally as the CN:fat ratio increased (Haddadin et al., 1995). By contrast, there was little effect of the milk $\mathrm{CN}$ :fat ratio on cheese chemical composition in the current study, although the range in values was less than that in other studies.

The fatty acid profile of the resultant cheese was very similar to that of the milk and was comparable to other studies that have examined the fatty acid content of sheep cheese (e.g., Nudda et al., 2005). Some studies reported an increase in CLA content of cheese during processing, which was attributed to the auto-oxidation of linoleic acid under anaerobic conditions during the heating step (Garcia-Lopez et al., 1994), but no such effect was observed here. The content of cis-9, trans-11 CLA in the cheese was lower in the current study, at $1.0 \mathrm{~g} / 100 \mathrm{~g}$ of total fatty acids, compared with $1.7 \mathrm{~g} / 100$ $\mathrm{g}$ in the study of Nudda et al. (2005), possibly because of the basal forage being hay, compared with grass. Grass contains high levels of 18:2n-6 and 18:3n-3, resulting in an increased duodenal flow of cis-9, trans-11 CLA and trans-11 18:1 and subsequent increased milk levels (Couvreur et al., 2006). Additionally, certain pastures may contain species with a higher content of 18:2n-6 or 18:3n-3 or with significant quantities of secondary plant compounds that can result in an increase in the content of CLA in cheese, possibly because of their inhibition of rumen biohydrogenation or their increase in $\Delta^{9}$-desaturase activity in the mammary tissue (Cabiddu et al., 2006).
The alterations in sensory perception of the cheese from +CLA ewes were likely related to changes in the milk fatty acid profile or were the result of the improved $\mathrm{CN}$ :fat ratio. For example, sheep cheese made from milk with a $\mathrm{CN}$ :fat ratio of 0.70 , the value recorded for milk from the +CLA ewes, was associated with a higher sensory rating compared with cheese made from milk with either lower or higher ratios (Haddadin et al., 1995). Other studies that examined the effect of CLA on sensory attributes of cheese from dairy cows reported that the CLA-enhanced products were less firm and crumbly (Jones et al., 2005), or that there were no significant differences in flavor or overall impression (Allred et al., 2006). In both the aforementioned studies, enhanced CLA levels were achieved by feeding combinations of fish oil and vegetable oil, which resulted in major shifts in other ruminal biohydrogenation intermediaries and in long-chain fatty acids such as eicosapentaenoic acid (20:5n-3) and docosahexaenoic acid (22:6n-3), which may impart their own flavor characteristics. There were fewer effects of feeding level on cheese sensory attributes in the current study, although the high feeding level was associated with a sourer, less yellow cheese. Few studies have examined the effect of level of feeding on the sensory attributes of cheese, although Agabriel et al. (2004) reported that in dairy cows, more intensive feeding systems were associated with a stronger aroma and odor intensity and a less elastic texture, although other factors such as season of production and ripening age had a greater influence.

\section{CONCLUSIONS}

The present study is the first in ruminants to examine the effect of a supplement containing trans-10, cis-12 CLA on milk fat and protein synthesis as it relates to the cheese fatty acid profile and sensory attributes. Supplementation of ewe diets with a lipid-encapsulated source of trans-10, cis-12 CLA reduced milk fat levels without affecting milk or milk protein yield; the magnitude of the reduction in milk fat and the increase in milk fat content of trans-10, cis-12 CLA were comparable to those of dairy cows at a similar dose (metabolic BW basis). Furthermore, the consequence of the reduction in milk fat was an improvement in the $\mathrm{CN}$ :fat ratio to the optimal value of 0.7 , whereas cheese yield was unaffected. The milk fatty acid content was shifted toward longer-chain fatty acids, and these changes were associated with improved sensory attributes of the cheese. Increasing the feeding level did not affect milk yield, with BW increasing instead, whereas the milk content of preformed fatty acids from the diet was decreased and there was only a small effect on the sensory attributes of the cheese. 


\section{ACKNOWLEDGMENTS}

The authors gratefully acknowledge the donation of the lipid-encapsulated supplement by BASF AG (Ludwigshafen, Germany). The authors acknowledge the support of J. Hargreaves, G. Vince, D. Ferguson, J. Cooper, and A. Ali at Harper Adams University College; C. Tyburczy, D. Dwyer, and B. Jones at Cornell University; M. J. de Veth at BASF AG, Germany; and G. R. Nute, Bristol University, for conducting the sensory assessment of the cheese.

\section{REFERENCES}

Agabriel, C., B. Martin, C. Sibra, J. Bonnefoy, M. Montel, R. Didienne, and S. Hulin. 2004. Effect of dairy production systems on the sensory characteristics of Cantal cheeses: A plant-scale study. Anim. Res. 53:221-234.

Agricultural and Food Research Council (AFRC). 1995. Energy and Protein Requirements of Ruminants. An advisory manual prepared by the AFRC Technical Committee on Responses to Nutrients. CAB International, Wallingford, Oxford, UK.

Allred, S. L., T. R. Dhiman, C. P. Brennand, R. C. Khanal, D. J. McMahon, and N. D. Luchini. 2006. Milk and cheese from cows fed calcium salts of palm and fish oil alone or in combination with soybean products. J. Dairy Sci. 89:234-248.

AOAC. 2000. Official Methods of Analysis. 17th ed. AOAC, Arlington, VA.

Bauman, D. E., and A. L. Lock. 2006. Conjugated linoleic acid: Biosynthesis and nutritional significance. Pages 93-135 in Advanced Dairy Chemistry, Vol. 2: Lipids. P. F. Fox and P. L. H. McSweeney, ed. Springer, New York, NY.

Bernal-Santos, G., J. W. Perfield, II, D. M. Barbano, D. E. Bauman, and T. R. Overton. 2003. Production responses of dairy cows to dietary supplementation with conjugated linoleic acid (CLA) during the transition period and early lactation. J. Dairy Sci. 86:3218-3228

Cabiddu, A., M. Addis, G. Pinna, S. Spada, M. Fiori, M. Sitzia, A. Pirisi, G. Piredda, and G. Molle. 2006. The inclusion of a daisy plant (Chrysanthemum coronarium) in dairy sheep diet. 1: Effect on milk and cheese fatty acid composition with particular reference to C18:2 cis-9, trans-11. Livest. Sci. 101:57-67.

Cannas, A., A. Pes, R. Mancuso, B. Vordet, and A. Nudda. 1998. Effect of dietary energy and protein concentration on the concentration of milk urea nitrogen in dairy ewes. J. Dairy Sci. 81:499-508.

Couvreur, S., C. Hurtaud, C. Lopez, L. Delaby, and J. L. Peyraud. 2006. The linear relationship between the proportion of fresh grass in the cow diet, milk fatty acid composition, and butter properties. J. Dairy Sci. 89:1956-1969.

de Veth, M. J., E. Castañeda-Gutiérrez, D. A. Dwyer, A. M. Pfeiffer, D. Putnam, and D. E. Bauman. 2006. Response to conjugated linoleic acid in dairy cows differing in energy and protein status. J. Dairy Sci. 89:4620-4631.

de Veth, M. J., J. M. Griinari, A. M. Pfeiffer, and D. E. Bauman. 2004. Effect of CLA on milk fat synthesis in dairy cows: Comparison of inhibition by methyl esters and free fatty acids, and relationships among studies. Lipids 39:365-372.

Garcia-Lopez, S., E. Echeverria, I. Tsui, and B. Balch. 1994. Changes in the content of conjugated linoleic acid (CLA) in processed cheese during processing. Feed Res. Int. 27:61-64.
Gargouri, A., G. Caja, R. Casals, and I. Mezghani. 2006. Lactational evaluation of effects of calcium soap of fatty acids on dairy ewes. Small Rumin. Res. 66:1-10.

Gellhorn, A., and W. Benjamin. 1964. The intracellular localization of an enzymic defect of lipid metabolism in diabetic rats. Biochim. Biophys. Acta 84:167-173.

Haddadin, M. S., R. M. A. Shahin, and R. K. Robinson. 1995. The influence of the casein:fat ratio in sheep's milk on the chemical composition and sensory properties on nabulis cheese. J. Soc. Dairy Technol. 48:71-75.

Hunter, E. A., and J. A. McEwan. 1998. Evaluation of an international ring trial for sensory profiling of hard cheese. Food Quality Pref. 9:343-354.

Jiang, J., L. Bjoerck, R. Fondén, and M. Emanuelson. 1996. Occurrence of conjugated cis-9, trans-11-octadecadienoic acid in bovine milk: Effects of feed and dietary regimen. J. Dairy Sci. 79:438445.

Johnson, M. E., C. M. Chen, and J. J. Jaeggi. 2001. Effect of rennet coagulation time on composition, yield, and quality of reducedfat Cheddar cheese. J. Dairy Sci. 84:1027-1033.

Jones, E. L., K. J. Shingfield, C. Kohen, A. K. Jones, B. Lupoli, A. S. Grandison, D. E. Beever, C. M. Williams, P. C. Calder, and P. Yaqoob. 2005. Chemical, physical, and sensory properties of dairy products enriched with conjugated linoleic acid. J. Dairy Sci. 88:2923-2937.

Lock, A. L., B. M. Teles, J. W. Perfield, II, D. E. Bauman, and L. A. Sinclair. 2006. A conjugated linoleic acid supplement containing trans-10, cis-12 reduces milk fat synthesis in lactating sheep. J. Dairy Sci. 89:1525-1532.

Nudda, A., M. A. McGuire, G. Battacone, and G. Pulina. 2005. Seasonal variation in conjugated linoleic acid and vaccenic acid in milk fat of sheep and its transfer to cheese and ricotta. J. Dairy Sci. 88:1311-1319.

Partington, E. C., L. A. Sinclair, A. M. Mackenzie, and J. Donaldson. 2004. The effects of metabolisable protein supply and machine milking on the periparturient relaxation of immunity against Teladorsagia circumcincta in dairy ewes. Page 10 in Proc. Br. Soc. Anim. Sci. Winter Mtg. Br. Soc. Anim. Sci., Edinburgh, UK.

Perfield, J. W., II, A. L. Lock, A. M. Pfeiffer, and D. E. Bauman. 2004. Effects of amide-protected and lipid-encapsulated conjugated linoleic acid (CLA) supplements on milk fat synthesis. J. Dairy Sci. 87:3010-3016.

Russell, A. J. F., J. M. Doney, and R. G. Gunn. 1969. Subjective assessment of body fat in live sheep. J. Agric. Sci. (Camb.) $72: 351-358$

Scott, R. 1981. Cheese Making Practice. Applied Science Publishers, London, UK.

Selberg, K. T., A. C. Lowe, C. R. Staples, N. D. Luchini, and L. Badinga. 2004. Production and metabolic responses of periparturient Holstein cows to dietary conjugated linoleic acid and transoctadecenoic acids. J. Dairy Sci. 87:158-168.

Soryal, K. A., S. S. Zeng, B. R. Min, S. P. Hart, and F. A. Beyene. 2004. Effect of feeding systems on composition of goat milk and yield of Domiati cheese. Small Rumin. Res. 54:121-129.

Sukhija, P. S., and D. L. Palmquist. 1988. Rapid method for determination of total fatty-acid content and composition of feedstuffs and feces. J. Agric. Food Chem. 36:1202-1206.

Wendorff, W. L. 2002. Milk composition and cheese yield. Pages 104117 in Proc. 7th Great Lakes Dairy Sheep Symp., Ithaca, NY. Dept. Anim. Sci., Univ. of Wisconsin, Madison.

Zhang, R. H., A. F. Mustafa, K. F. Ng-Kwai-Hang, and X. Zhao. 2006 Effects of freezing on composition and fatty acid profiles of sheep milk and cheese. Small Rumin. Res. 64:203-210. 